\title{
IN-VIVO AND IN-VITRO STUDIES OF THE EFFECT OF SPECIFIC ANTITOXIN ON THE PHAGOCYTOSIS OF CELLS OF CLOSTRIDIUM BOTULINUM TYPE A
}

\section{J. B. Suzuki and N. GreCZ}

Department of Biology, Illinois Institute of Technology, Chicago, Illinois, and the Departments of Pathology and Obstetrics-Gynecology, St Luke's Hospital Center, Amsterdam at 114th St., New York, N.Y. 10025, USA

PATHOGENICITY of Clostridium botulinum type-A spores in vivo has been extensively studied in our laboratory (Booth, Suzuki and Grecz, 1971 $a$; Suzuki et al., 1971) and by others (Coleman and Meyer, 1922; Starin and Dack, 1925; Keppie, 1951). When spores of $\mathrm{Cl}$. botulinum type A are introduced into the peritoneal cavity of experimental animals, they are engulfed by macrophages and polymorphonuclear (PMN) leucocytes and they then germinate (Booth, Suzuki and Grecz, 1971b). In in-vitro studies, spores of $\mathrm{Cl}$. botulinum have been shown to germinate and to release spore-bound toxin within $8 \mathrm{hr}$ in guinea-pig leucocyte systems (Suzuki, Booth and Grecz, 1970). Although botulism is primarily regarded as the result of the ingestion of preformed toxin, it may be argued that the unexplained delay in the appearance of symptoms in some cases might be attributable to the delayed release of cell-bound toxin. Ingestion of sublethal amounts of $\mathrm{Cl}$. botulinum spores, vegetative cells, or toxin in contaminated food, or growth of $\mathrm{Cl}$. botulinum in the gastrointestinal tract or in wounds, may subject the host to minute quantities of toxin, but it is unlikely that significant amounts of antitoxin would arise in the host in this way, since the immunising dose is probably much greater than the lethal dose. The presence of spores in the host has been reported in cases of botulinal food poisoning (Coleman and Meyer) and wound infections (Davis, Mattman and Wiley, 1951; Thomas, Keleher and McKee, 1951; Dolman, 1961; Donadio and Gangarosa, 1970; U.S. Public Health Service, 1971 $a$ and $b$ ).

Immediate passive immunisation with equine antisera and specific neutralisation of the ingested toxin is at present the only efficacious treatment for patients with botulism (Harrell, Green and Winn, 1964). Because specific antitoxin forms complexes with botulinal cells, it is of interest to know whether specific antitoxin influences phagocytic processes and toxin release. The present paper reports studies that we have performed in vivo in mice and in vitro in guinea-pig-leucocyte tissue cultures.

\section{MATERIALS AND METHODS}

Culture methods. A culture of Clostridium botulinum type A, strain 33A, was inoculated into a 5-1 flask containing trypticase-peptone (TP) broth: 5 per cent. Trypticase, 0.5 per

Received 19 May 1972; accepted 21 Aug. 1972.

Requests for reprints should be sent to the Department of Biology, Illinois Institute of Technology, Chicago, Illinois 60616, USA.

J. MED. MICROBIOL.-VOL. 6 (1973) 
cent. peptone, $0 \cdot 1$ per cent. sodium thioglycollate, and $20 \mu \mathrm{c}$ per litre of ${ }^{45} \mathrm{Ca}$ (International Chemical and Nuclear Corp., Irvine, Calif.). After incubation for 6 days at $30^{\circ} \mathrm{C},{ }^{45} \mathrm{Ca}$ labelled spores were harvested and vegetative cell contaminants were removed as previously described (Grecz, Anellis and Schneider, 1962).

Experimental animals. White Swiss-Webster mice were raised for 12 generations in a closed colony in a thermostatically controlled room at the Illinois Institute of Technology. They were fed and watered ad libitum with Rockland rat and mouse diet, and they weighed 20-25 $\mathrm{g}$ when used. Hartley strain guinea-pigs were raised for six generations under similar conditions with the exception that the Rockland guinea-pig diet was supplemented weekly with lettuce and greens. Guinea-pigs weighed $600-800 \mathrm{~g}$ when used.

Leucocyte preparations. Suspensions of approximately 85-90 per cent. PMN leucocytes were obtained from guinea-pig peritoneal exudate by a modification of the method of Sbarra and Karnovsky (1959). Briefly, guinea-pigs received an intraperitoneal injection of $20 \mathrm{ml}$ of 8 per cent. sterile sodium caseinate in 0.85 per cent. $\mathrm{NaCl}$. Eighteen hr later, the peritoneal cavity was flushed with $15 \mathrm{ml}$ of warm 0.85 per cent. $\mathrm{NaCl}$ and the collected cells were washed in Hanks' Balanced Salt Solution (HBSS, Grand Island Biol. Co., Grand Island, N.Y.). Leucocyte counts were determined by standard clinical laboratory procedures with a haemocytometer.

Clostridium botulinum specific antitoxin. Specific Cl. botulinum type A antitoxin of equine origin was obtained from Burroughs-Wellcome (Tuckahoe, N.Y.). This antitoxic serum probably contains small amounts of antibacterial and antisporal antibodies.

Antibody treatment of spores. One $\mathrm{ml}$ of specific antitoxin was mixed with $1 \mathrm{ml}$ of a suspension containing ${ }^{45} \mathrm{Ca}$-labelled $\mathrm{Cl}$. botulinum spores $\left(10^{9}\right.$ per $\left.\mathrm{ml}\right)$ for $1 \mathrm{hr}$ at $37^{\circ} \mathrm{C}$ in a shaking waterbath. It has been reported that antitoxin binds selectively to the outer coats of $\mathrm{Cl}$. botulinum spores (Duda and Slack, 1969). The spores were then centrifuged at $100 \mathrm{~g}$ for $30 \mathrm{~min}$. and washed thrice with HBSS to remove unattached equine specific antitoxin. The antitoxin-treated spores were resuspended in $1 \mathrm{ml} \mathrm{HBSS}$.

Phagocytic indices (PI) were determined by the radioisotope method of Suzuki, Booth and Grecz (1971b). Briefly, suspensions of guinea-pig PMN leucocytes $\left(10^{7}\right.$ per $\left.\mathrm{ml}\right)$ and ${ }^{45} \mathrm{Ca}$-labelled $\mathrm{Cl}$. botulinum type A spores $\left(10^{9}\right.$ per $\left.\mathrm{ml}\right)$, untreated and treated with specific antitoxin in separate series, were incubated in 30 per cent. non-immune guinea-pig serum (Animal Blood Center, Syracuse, N.Y.) and HBSS at $37^{\circ} \mathrm{C}$. Equal portions of these systems were taken at $0,3,5,15,30,60$ and 120 min., filtered through a Millipore Swinney $(5 \mu \mathrm{m})$ filter (Millipore Corp., Bedford, Mass.) and rinsed with 0.85 per cent. $\mathrm{NaCl}$. The filter pad retaining PMN leucocytes and engulfed labelled spores was dried $\left(55^{\circ} \mathrm{C}, 30 \mathrm{~min}\right.$.) and placed in a glass scintillation vial; $10 \mathrm{ml}$ Bray's solution (Bray, 1960) was added, and the suspension was held at $14^{\circ} \mathrm{C}$ until counted.

In-vivo experimental systems. In-vivo analyses of the action of specific antitoxin on Cl. botulinum spores were made by two methods:

Method 1 involved periodic culturing of peritoneal exudates of mice after intraperitoneal challenge with specific antitoxin-treated $\mathrm{Cl}$. botulinum spores. Mice weighing $20-25 \mathrm{~g}$ received $10^{7}$ heat-resistant $\left(80^{\circ} \mathrm{C}, 15 \mathrm{~min}\right.$.) spores intraperitoneally. At appropriate time intervals, $0,1,6,12,24,48$ and $72 \mathrm{hr}$ for non-immunised mice and $0,1,2,3$, $5,7,14$ and 21 days for passively immunised mice, $1 \mathrm{ml}$ of sterile HBSS was introduced into the peritoneal cavity. The peritoneal fluid was then extracted with a syringe, measured and diluted 1 in 10 in sterile distilled $\mathrm{H}_{2} \mathrm{O}$. Further logarithmic dilutions were made and plated anaerobically in Wynne's medium (Wynne, Schmieding and Daye, 1955). Identical procedures were followed for observations on heat-resistant cells except that all dilution tubes were subjected to heating at $80^{\circ} \mathrm{C}$ for $15 \mathrm{~min}$., which destroys germinated spores and vegetative cells of $\mathrm{Cl}$. botulinum.

Method 2 involved determination of free ${ }^{45} \mathrm{Ca}$ appearing in the urine of mice challenged intraperitoneally with ${ }^{45} \mathrm{Ca}$-labelled $\mathrm{Cl}$. botulinum spores; the ${ }^{45} \mathrm{Ca}$ in the urine served as an indicator of germination (Powell and Strange). Twelve mice were each given by injection $10^{8}{ }^{45} \mathrm{Ca}$-labelled spores per ml (activity of $2000 \mathrm{CPM}$ per $\mathrm{ml}$ ), untreated and specific antitoxin-treated spores being used in separate series, and placed in a plastic 
metabolic chamber constructed to collect urine and to strain out faecal matter. Urine samples were collected at $0,2,4,6,8,12,18,24$ and $32 \mathrm{hr}$ in a plastic conical centrifuge tube and stored at $14^{\circ} \mathrm{C}$ until radioactivity was counted. An additional urine sample (at $40 \mathrm{hr}$ ) was taken from passively immunised mice. Microscopic analyses of urine were carried out by standard clinical laboratory procedures.

In-vitro experimental systems. In-vitro analyses of the action of specific antitoxin on leucocyte-induced germination were also provided by the assay of ${ }^{45} \mathrm{Ca}$ released during spore germination. Suspensions of guinea-pig PMN leucocytes $\left(10^{7} \mathrm{per} \mathrm{ml}\right)$ and $\mathrm{Cl}$. botulinum type-A spores $\left(10^{8}\right.$ per $\left.\mathrm{ml}\right)$ were incubated at $37^{\circ} \mathrm{C}$. At $0,2,4,6,12,18,24$ and $48 \mathrm{hr}$, $1 \cdot 1-\mathrm{ml}$ portions of this suspension were filtered through a Millipore Swinney $(0.22 \mu \mathrm{m})$ filter as previously described (Suzuki, Booth and Grecz, 1971b). A 0.1-ml volume of this filtrate was placed in a glass scintillation vial; $10 \mathrm{ml}$ Bray's solution was added and the mixture was stored at $14^{\circ} \mathrm{C}$ until radioactivity was counted. The remaining $1 \mathrm{ml}$ was injected intraperitoneally into white mice to assay for presence of botulinal type-A toxin. Concurrent control systems included $(a)$ non-specific antibody-treated ${ }^{45} \mathrm{Ca}$-labelled spores $\left(10^{8} \mathrm{per} \mathrm{ml}\right)+$ guinea-pig PMN leucocytes $\left(10^{7}\right.$ per $\left.\mathrm{ml}\right),(b)$ specific antitoxic serum-treated ${ }^{45} \mathrm{Ca}$-labelled spores $\left(10^{8}\right.$ per $\left.\mathrm{ml}\right)$ in TP broth, and $(c)$ non-specific antitoxic serum-treated ${ }^{45} \mathrm{Ca}$-labelled spores $\left(10^{8}\right.$ per $\left.\mathrm{ml}\right)$ in TP broth.

Radioactivity determinations. Suspensions were held in scintillation vials at $14^{\circ} \mathrm{C}$ for 10 min. in a Beckman LS-200 Liquid Scintillation Counter.

\section{RESULTS}

\section{Animal experiments}

As shown in fig. 1, after intraperitoneal injection into Swiss-Webster mice, spores of $\mathrm{Cl}$. botulinum type A undergo a gradual conversion to heat-sensitive cells (germinated spores or vegetative cells, or both). This conversion reaches a maximum at $24 \mathrm{hr}$ and then there is a decline in recoverable heat-sensitive cells. Bacterial counts of the fluids from the peritoneal cavity of normal mice unchallenged in this way were, on average $(\mathrm{n}=7), 10^{3}$ heat-labile $\left(80^{\circ} \mathrm{C}\right.$, $15 \mathrm{~min}$.) and $10^{2}$ heat-resistant cells of heterogeneous commensal organisms.

Completely different results were obtained when the experiment was done with mice that had been passively immunised with specific antitoxin. The results given in fig. 2, show that clearance of heat-resistant spores was much slower than in non-immunised mice. Some heat-sensitive cells appeared but only after 5 days, and the number of heat-sensitive cells even after 14 to 21 days did not approach that in non-immunised mice.

Fig. 3 complements in-vivo data discussed above. Here, the release of ${ }^{45} \mathrm{Ca}$ in the urine of mice challenged intraperitoneally with labelled $\mathrm{Cl}$. botulinum spores (both specific antitoxin-treated and non-treated) was assayed as an index of spore germination within the animal body. Taking into consideration the 4-hr period for normal urinary clearance of free ${ }^{45} \mathrm{Ca}$ injected intraperitoneally (Suzuki et al., 1971b) and subtracting this time from the point of appearance of ${ }^{45} \mathrm{Ca}$ in the urine, in-vivo germination times of $\mathrm{Cl}$. botulinum spores can be estimated. Control, non-treated spores germinated at $8 \mathrm{hr}$ post-injection and excreted a maximum of 22,000 counts per minute (CPM) at $18 \mathrm{hr}$. Antibody-treated spores began to germinate at $8 \mathrm{hr}$, but the extent of germination was depressed by 64 per cent. compared with control values. This unexpected in-vivo observation prompted us to investigate the problem 
further with more definitive in-vitro guinea-pig phagocytic systems. In particular, it was important to study whether complexing of spores with specific antitoxin may prevent their germination.

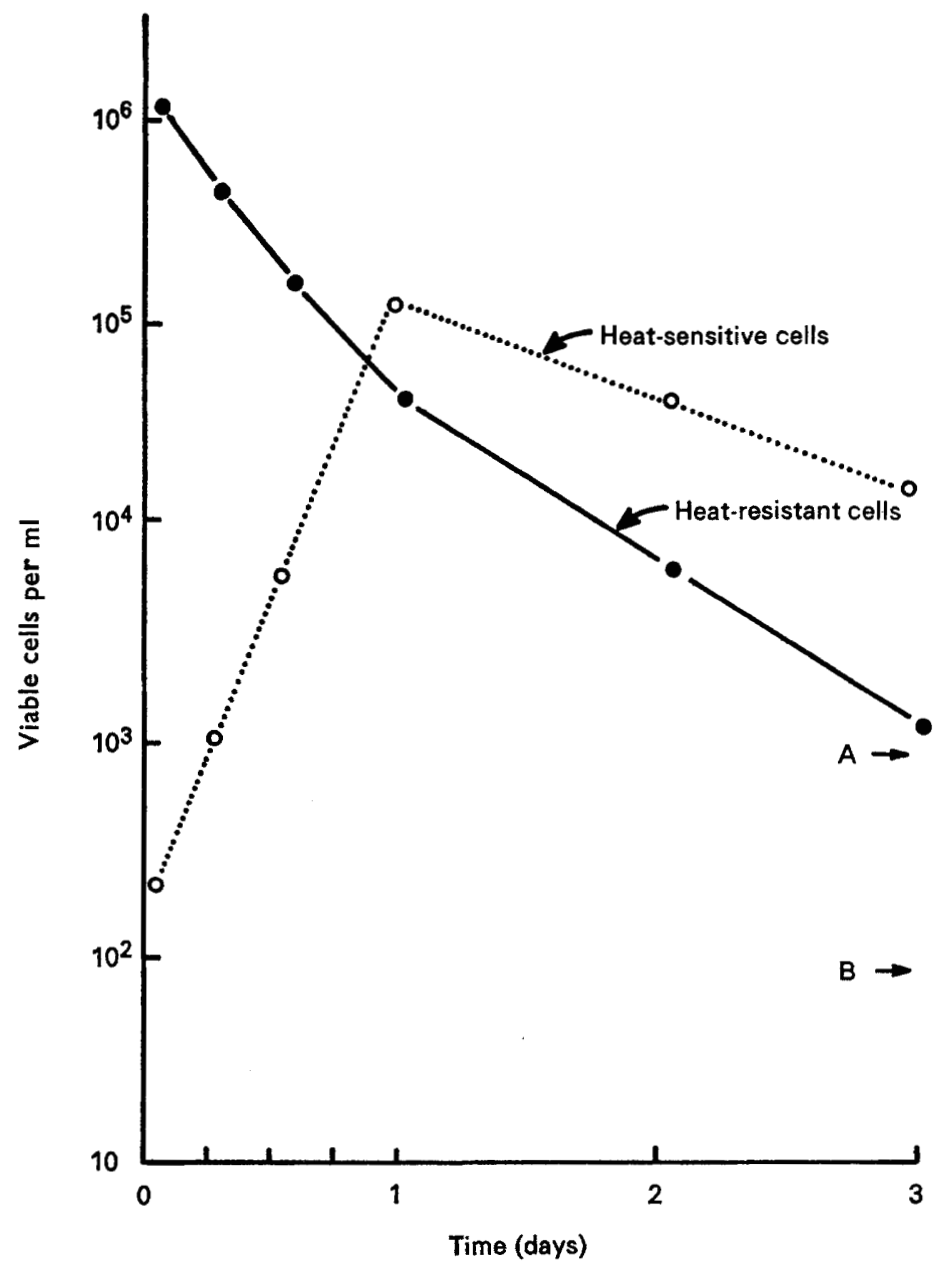

FIG. 1.-Numbers of heat-resistant cells (spores) and heat-sensitive cells (germinated spores and vegetative cells) of $\mathrm{Cl}$. botulinum type A in the peritoneal cavity of non-immunised mice after intraperitoneal injection of 108 heat-resistant spores. $\mathrm{A}=$ Heat-sensitive cells, $\mathrm{B}=$ heatresistant cells, recovered from unchallenged control mice. (Data from means of three experiments.)

\section{In-vitro studies}

Studies with spores. Table I shows that phagocytic indices (PI) of specific antitoxin-treated spores were actually increased by 4-8 per cent. for $\mathrm{Cl}$. botulinum type-A spores when compared with non-treated spores in a similar in-vitro leucocyte system. This opsonic effect was not unexpected.

On the other hand, spore germination, as monitored by release of free ${ }^{45} \mathrm{Ca}$ in filtrates, was greatly retarded when labelled spores were pretreated with 
specific antitoxin (fig. 4). The inhibition of germination by complexing of spores with specific antitoxin was greater than 50 per cent. compared with control in-vitro systems of non-specific antitoxin-treated $\mathrm{Cl}$. botulinum type-A

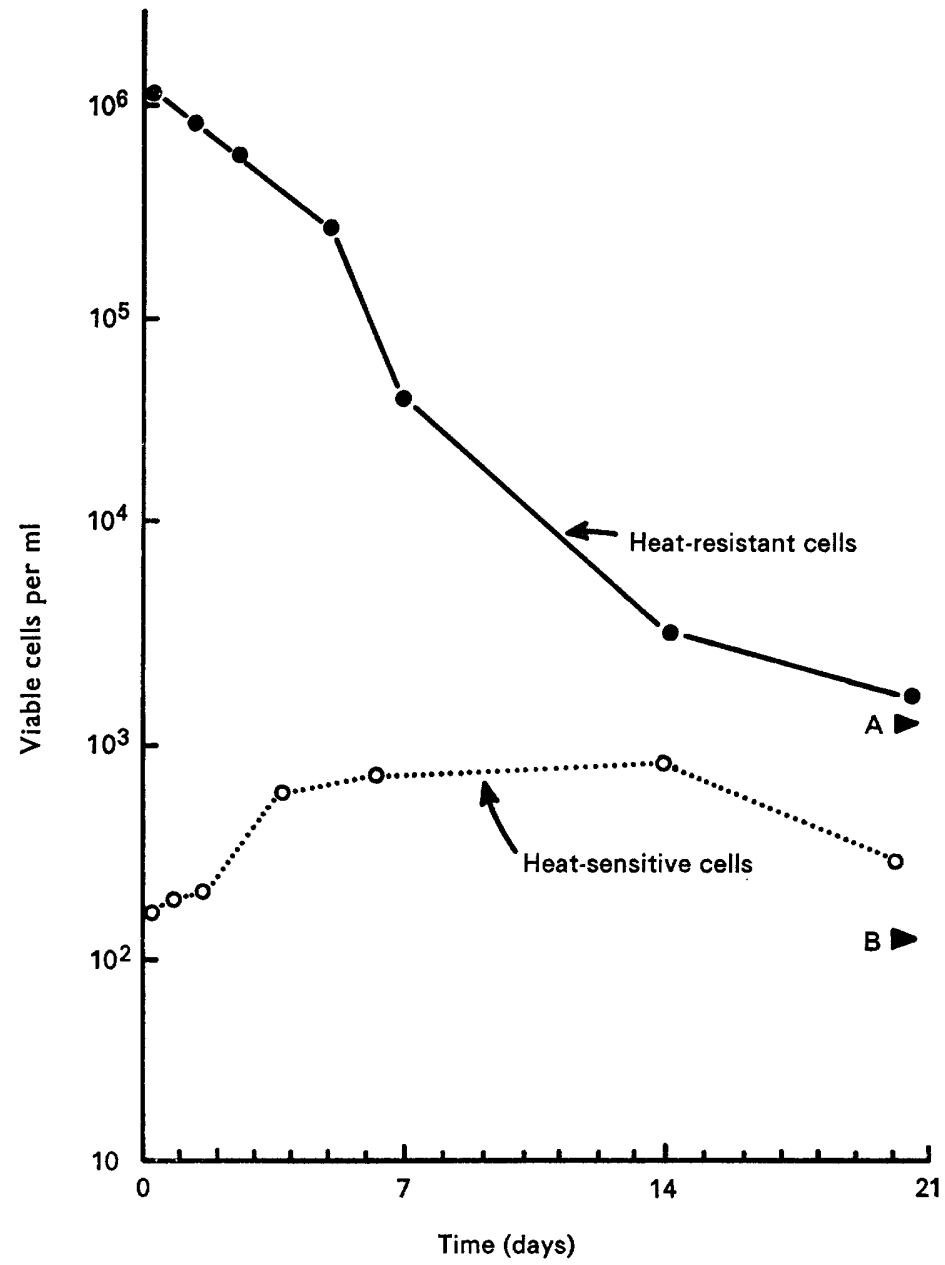

Fig. 2.-Numbers of heat-resistant cells (spores) and heat-sensitive cells (germinated spores and vegetative cells) of $\mathrm{Cl}$. botulinum type $\mathrm{A}$ in the peritoneal cavity of antibody-protected mice after intraperitoneal injection of $10^{8}$ heat-resistant spores. $\mathrm{A}=$ Heat-sensitive cells, $\mathrm{B}=$ heatresistant cells, recovered from unchallenged control mice. (Data from means of three experiments.)

spores. Under similar conditions, spores pretreated with anti-bovine serum albumin exhibited normal germination when incubated with leucocytes. This indicates that the action of antitoxin was specific.

Toxin release from $\mathrm{Cl}$. botulinum spores, as determined by mouse intraperitoneal assay of $0.22 \mu \mathrm{m}$ filtrates, was almost completely prevented in the leucocyte in-vitro system and in TP broth when spores were pretreated with specific antitoxin (table II). Normally, with untreated control spores, botulinal toxin was released at 12-48 $\mathrm{hr}$ when spores were incubated in TP broth or 
with $10^{7}$ guinea-pig leucocytes. Toxin release may serve as another index of germination and outgrowth of $\mathrm{Cl}$. botulinum spores (Tang and Grecz, 1968).

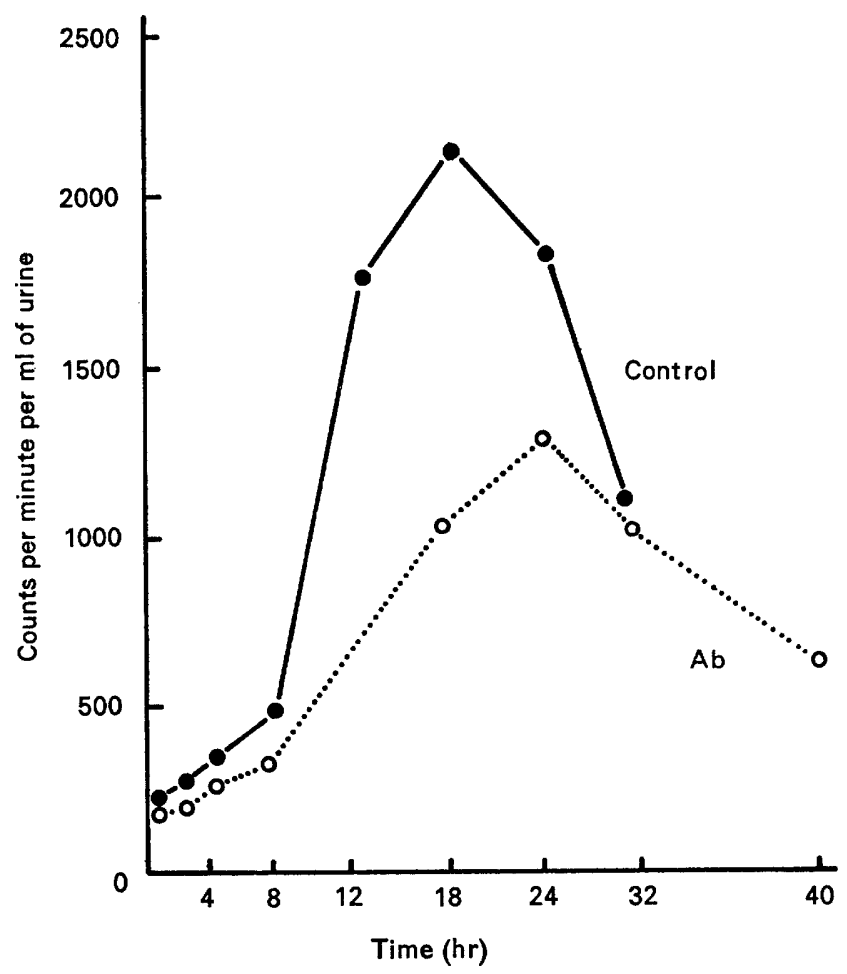

FIG. 3.-Appearance of free ${ }^{45} \mathrm{Ca}$ in the urine of 12 mice after intraperitoneal injection of $10^{8}$ labelled spores of $\mathrm{Cl}$. botulinum type A that were untreated (control) and treated with specific antibody $(\mathrm{Ab})$. (The data presented are means of three experiments. The background counts have been deducted.)

\section{TABLE I}

Phagocytic indices of ${ }^{45} \mathrm{Ca}$-labelled spores of $\mathrm{Cl}$. botulinum type $\mathrm{A}\left(10^{8} \mathrm{per} \mathrm{ml}\right)$ treated with botulinal type- $A$ specific antibody $(A b)$ and incubated in vitro with guinea-pig leucocytes (107 per $\mathrm{ml})$, and comparative data for spores untreated with antibody

\begin{tabular}{|c|c|c|}
\hline \multirow[b]{2}{*}{$\underset{(\min .)}{\text { Time }}$} & \multicolumn{2}{|c|}{ Phagocytic index (per cent.) for } \\
\hline & $\begin{array}{l}\text { Ab-treated } \\
\text { spores }\end{array}$ & $\begin{array}{l}\text { untreated } \\
\text { spores }\end{array}$ \\
\hline $\begin{array}{r}1 \\
3 \\
5 \\
15 \\
30 \\
60 \\
120\end{array}$ & $\begin{array}{l}30 \\
39 \\
44 \\
74 \\
40 \\
31 \\
28\end{array}$ & $\begin{array}{l}28 \\
38 \\
40 \\
66 \\
41 \\
39 \\
21\end{array}$ \\
\hline
\end{tabular}

The results in table II relating to inhibition of toxin release by specific antitoxin are in agreement with the data given in fig. 2 on specific antitoxin 
inhibition of spore clearance from the animal body, and in figs. 3 and 4 on inhibition of ${ }^{45} \mathrm{Ca}$ release in vivo and in vitro. Altogether, it is clear that the complexing of spores with specific antitoxin, although enhancing initial spore engulfment, subsequently prevents germination and consequent disintegration of $\mathrm{Cl}$. botulinum spores within the leucocytes.

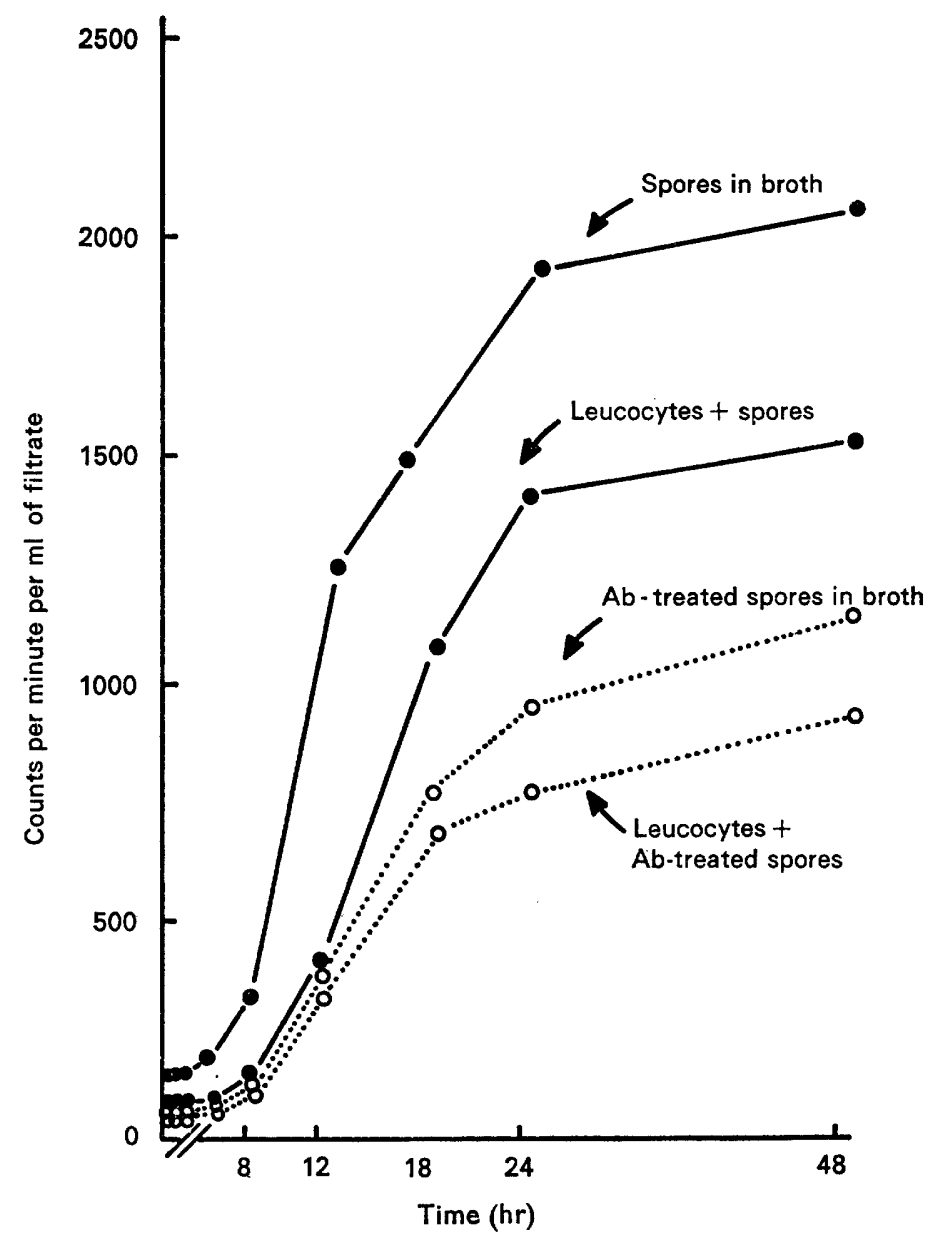

FIG. 4.-The release of free ${ }^{45} \mathrm{Ca}$ in filtrates derived from mixtures of guinea-pig polymorphonuclear leucocytes and $45 \mathrm{Ca}$-labelled spores of $\mathrm{Cl}$. botulinum treated with specific antibody (Ab) and incubated in vitro at $37^{\circ} \mathrm{C}$. (Data from means of four experiments. Background counts have been subtracted.)

The results indicate that complexing of specific antitoxin with the spore blocked either one of two distinct processes known to occur during phagocytosis: (i) spore germination (Suzuki et al., 1970), and/or (ii) lysis of outgrowing cells within the phagocyte.

Evidence that spore germination was blocked by specific antitoxin was evident from retention of ${ }^{45} \mathrm{Ca}$ and of spore toxin, and from maintenance of 
the spores' heat-resistance. However, the influence of antitoxin treatment on the lysis of spores after germination or outgrowth remained obscure.

TABLE II

Effect of pretreatment with antibody $(A b)$ on the release of toxin from spores of $C l$. botulinum type $A$ incubated at a concentration of $10^{8} \mathrm{per} \mathrm{ml}$ in the indicated in-vitro systems

\begin{tabular}{|c|c|c|c|c|}
\hline \multirow[b]{3}{*}{$\underset{(\mathrm{hr})}{\operatorname{Time}}$} & \multicolumn{4}{|c|}{$\begin{array}{l}\text { Number of mice dead out of total challenged during } \\
\text { the stated period* with filtrate from }\end{array}$} \\
\hline & \multicolumn{2}{|c|}{ untreated spores } & \multicolumn{2}{|c|}{ Ab-treated spores } \\
\hline & $\begin{array}{l}\text { in leucocyte } \\
\text { systems } \dagger\end{array}$ & $\mathbf{T P}$ broth & $\begin{array}{l}\text { in leucocyte } \\
\text { systems } \dagger\end{array}$ & TP broth \\
\hline $0-12$ & 0 & 0 & 0 & 0 \\
\hline $12-48$ & 16 & 16 & 0 & 4 \\
\hline
\end{tabular}

* Assays for toxicity were carried out by intraperitoneal injection of $1 \mathrm{ml}$ filtrate into groups of four mice at $0,2,4,6,12 \mathrm{hr}$ (total 20 mice) and 18, 24, 36 and $48 \mathrm{hr}$ (total 16 mice).

$\dagger$ Guinea-pig leucocytes (107 per $\mathrm{ml}$ ).

Studies with vegetative cells. To study the latter point, vegetative cells of $\mathrm{Cl}$. botulinum type A in the 6 th $\mathrm{hr}$ of log-phase growth were treated with specific antitoxin for $2 \mathrm{hr}$ at $37^{\circ} \mathrm{C}$, washed with HBSS three times, and subjected to guinea-pig leucocytes. As shown in table III, engulfment of vegetative cells was enhanced by specific antitoxin treatment, because slightly higher PI were recorded for specific antitoxin-treated cells.

TABLE III

Phagocytic indices of ${ }^{45} \mathrm{Ca}$-labelled vegetative cells of $\mathrm{Cl}$. botulinum type $\mathrm{A}$ (108 per $\mathrm{ml}$ ) treated with specific antibody $(A b)$ and incubated in vitro with guinea-pig leucocytes $\left(10^{7} \mathrm{per} \mathrm{ml}\right)$, and comparative data for cells untreated with antibody

\begin{tabular}{r|cc}
\hline \multirow{2}{*}{$\begin{array}{c}\text { Time } \\
\text { (min.) }\end{array}$} & $\begin{array}{c}\text { Ab-treated } \\
\text { vegetative } \\
\text { cells }\end{array}$ & $\begin{array}{c}\text { untreated } \\
\text { vegetative } \\
\text { cells }\end{array}$ \\
\cline { 2 - 3 } 1 & 28 & 25 \\
3 & 36 & 35 \\
5 & 41 & 38 \\
15 & 69 & 62 \\
30 & 35 & 39 \\
60 & 21 & 23 \\
\hline
\end{tabular}

The results recorded in table IV show that complexing of vegetative cells with specific antitoxin completely prevented leucocytic digestion. Untreated cells were digested and lost toxin into the cell-free filtrate immediately after engulfment ( $0-12 \mathrm{hr}$, see table IV), whereas no toxin was released from engulfed 
specific antitoxin-treated vegetative cells even after $48 \mathrm{hr}$, as is evident from the survival of all four mice challenged with the cell-free filtrates.

The data given in table IV also show that specific antitoxin-treated vegetative cells of $\mathrm{Cl}$. botulinum type A released some toxin in TP broth; one mouse died of four challenged with the cell-free broth. This seems to indicate that some autolysis or growth of the cells, or both, occurred in TP broth-or, alternatively, that some of the toxin in the vegetative cells was not accessible to specific antitoxin and thus was not neutralised during the initial treatment with specific antitoxic serum.

TABLE IV

Effect of pretreatment with antibody $(A b)$ on the release of toxin from vegetative cells of Cl. botulinum type $\mathrm{A}\left(10^{8} \mathrm{per} \mathrm{ml}\right)$ incubated in the indicated in-vitro systems

\begin{tabular}{|c|c|c|c|c|}
\hline \multirow[b]{3}{*}{$\begin{array}{l}\text { Time } \\
\text { (hr) }\end{array}$} & \multicolumn{4}{|c|}{$\begin{array}{l}\text { Number of mice dead out of total challenged during } \\
\text { the stated period* with filtrate from }\end{array}$} \\
\hline & \multicolumn{2}{|c|}{ untreated cells } & \multicolumn{2}{|c|}{ Ab-treated cells } \\
\hline & $\begin{array}{l}\text { in leucocyte } \\
\text { systems } \dagger\end{array}$ & in & $\begin{array}{c}\text { in leucocyte } \\
\text { systems } \dagger\end{array}$ & in \\
\hline $0-12$ & 20 & 15 & 0 & 5 \\
\hline $12-48$ & 16 & 16 & $\mathbf{0}$ & 4 \\
\hline
\end{tabular}

* See footnotes to table II.

\section{DisCUSSION}

The findings confirm our earlier reports that intraperitoneally injected spores of Clostridium botulinum type A can germinate in vivo in non-immunised mice to yield heat-sensitive cells (Booth, Suzuki and Grecz, 1971 $a$ and $b$ ). After $24 \mathrm{hr}$, however, the number of heat-sensitive cells declined, indicating either continual clearance from the peritoneal cavity by the reticuloendothelial (RES) system or phagocytic degradation of the heat-sensitive cells, or both. On the other hand, when specific antitoxin-treated spores were injected intraperitoneally into mice, heat-sensitive cells were detected in negligible numbers up to 21 days. When untreated spores were injected into passively immunised mice, they decreased in number but much more slowly than in non-immunised mice. The gradual decrease is probably the result of continued RES clearance and not attributable to conversion to germinated spores or vegetative cells. This conclusion appears to be confirmed by our observation that antitoxin-treated spores did not lose any significant amounts of ${ }^{45} \mathrm{Ca}$ into urine; in contrast, urinary ${ }^{45} \mathrm{Ca}$ appeared at $12 \mathrm{hr}$ from control untreated spores indicating that massive germination of control spores commenced at $8 \mathrm{hr}$ after injection (Suzuki, Booth and Grecz, 1971b).

Our findings may explain the delayed course of toxi-infection (Minervin, 1967) lasting 5 to 13 days when botulinal toxin production and growth of the 
organisms develops gradually in the gut and other organs. Under these conditions a mild generalised $\mathrm{Cl}$. botulinum infection initiates a balanced interaction between generation of toxin and organisms in the body and production of specific antitoxin by the lymphoid system. Relapse, such as observed by Minervin, would be expected whenever multiplication of the organisms and attendant toxin synthesis outweighed production of specific antitoxin. Enhanced engulfment of spores after complexing with specific antitoxin is probably due to changes in their surface properties and to opsonic action similar to that described for a number of vegetative micro-organisms (Cohn and Morse, 1960).

Proof that engulfment of spores did indeed occur is crucial to further discussion of PMN leucocyte-induced spore germination. For the purpose of the present analysis, the process of phagocytic attack on spores of $\mathrm{Cl}$. botulinum may be divided into four major steps:

(1) initial contact and engulfment;

(2) germination of engulfed spores signified by release of contained ${ }^{45} \mathrm{Ca}$ and loss of heat resistance;

(3) lysis and destruction of germinated spores (or vegetative cells) due to the action of a number of lytic enzymes from the leucocyte and the spore; and

(4) excretion of released products, particularly of botulinal toxin.

It has been previously demonstrated (Suzuki et al., 1970; and Suzuki, Booth, Benedik and Grecz, 1971) that engulfment of spores by leucocytes is normally followed by germination and that, at stage 1 , the spores are fully dormant. The second step, spore germination in the leucocyte, may proceed by at least two alternative routes: (i) it may be triggered by free amino acids initiating normal physiological germination, or (ii) it may be induced by lytic enzymes and reactive molecules in the leucocyte, such as glutathione reductase, lysozyme or other lysosomal enzymes and $\mathrm{H}_{2} \mathrm{O}_{2}$. Complexing of the spore with specific antitoxin appears to block both of these routes: there was lack of germination and release of ${ }^{45} \mathrm{Ca}$ and of botulinal toxin in TP broth where route (i) would be expected to operate, and in guinea-pig leucocytes where route (ii) would be prominent.

Concerning the third step, it is remarkable that specific antitoxin, a $\gamma$ globulin, is not attacked by enzymes in the leucocyte, and that complexing of the specific antitoxin effectively blocks digestion of cells, particularly vegetative forms which are normally readily attacked. This suggests at least three possibilities: (a) protease activity in the leucocyte may be extremely low; $(b)$ there might be a physical barrier in the spore structure, e.g., the small size of pores in the coat, that prevents contact of protein molecules with proteolytic enzymes; and $(c)$ there may be complexing of specific antitoxin with spore toxin, which is known to be located at the spore coat surface (Duda and Slack, 1969). This may physically decrease the permeability of the spore coat so that lytic enzymes in the leucocyte or germination agents in TP broth cannot reach the 
appropriate substrates or germination receptor sites. Furthermore, the toxin molecule is known to resist for rather long periods of time exposure to trypsin (Bonventre and Kempe, 1960) and to mixed microbial flora (Grecz, Wagenaar and Dack, 1965).

The present experiments demonstrate that complexing of specific antitoxin with $C l$. botulinum cells has a dual effect: (i) an opsonic action promoting phagocytic engulfment of spores or vegetative cells, and (ii) inhibition of germination or cell digestion, or both, after engulfment.

The inability of leucocytes to cope with specific antitoxin-treated spores and/or vegetative cells of $\mathrm{Cl}$. botulinum provides an explanation for reported cases of botulism in which the onset of symptoms appeared to be unduly delayed or gradual. It may also be of significance in the pathogenesis of intestinal toxi-infection and wound infections with actively growing cell populations of $\mathrm{Cl}$. botulinum in vivo.

The basis of these chronic processes may be that the host exposed to sublethal amounts of toxin eventually generates specific antitoxin. In turn the specific antitoxin actually favours the $\mathrm{Cl}$. botulinum present in the body by facilitating their engulfment, preventing their destruction within the leucocyte, and enhancing their dissemination.

\section{SUMMARY}

The conversion of heat-resistant spores of Clostridium botulinum type A into germinated heat-sensitive cells in the peritoneal cavity of mice has been observed. This in-vivo germination of spores was depressed in mice passively immunised with type-A botulinal antitoxin. Studies, in which the release of free ${ }^{45} \mathrm{Ca}$ in the urine of mice challenged with labelled $\mathrm{Cl}$. botulinum spores provided an indicator of spore germination, showed that spore germination occurred normally at $8 \mathrm{hr}$ in vivo. However, the rate of germination as determined from ${ }^{45} \mathrm{Ca}$ excretion was substantially inhibited when antibody-treated spores were used as the challenge.

In in-vitro studies with guinea-pig leucocytes, spore germination was similarly assayed by monitoring the release of ${ }^{45} \mathrm{Ca}$ from labelled spores. Spore germination in these leucocyte systems was also suppressed when the spores were first treated with $\mathrm{Cl}$. botulinum type-A antitoxic serum, although phagocytic indices for antibody-treated spores and vegetative cells were increased. Release of type-A botulinal toxin was either completely prevented or substantially suppressed when $C l$. botulinum spores and vegetative cells were treated with specific botulinal antibody and incubated with leucocytes.

These results demonstrate that combination of spores with type-specific antibody prompted phagocytic engulfment of antibody-coated spores, but strongly inhibited subsequent phagocytic digestion of engulfed spores.

The assistance of Andrew Benedik of Chicago Osteopathic Medical School is greatly appreciated. This investigation was supported by Public Health Service Grant FD-00358 from the Food and Drug Administration, Consumer Protection and Environmental Health Service. 


\section{REFERENCES}

BonVentre, P. F., AND KEMPE, L. L. 1960. Physiology of toxin production by Clostridium botulinum Types A and B. IV. Activation of the toxin. J. Bact., 79, 24.

Booth, R., SuzukI, J. B., AND Grecz, N. 1971a. Pathogenesis of Clostridium botulinum type A: In vivo fate of $C$. botulinum spores following intraperitoneal challenge. Trans. Ill. State Acad. Sci., 64, 147.

Booth, R., SuzukI, J. B., AND Grecz, N. 1971 b. Sequential use of Wright's and ZiehlNeelsen's stains for demonstrating phagocytosis of bacterial spores. Stain Technol., 46, 23.

Bray, G. A. 1960. A simple efficient liquid scintillator for counting aqueous solutions in a liquid scintillation counter. Analyt. Biochem., 1, 279.

CoHN, Z. A., AND Morse, S. I. 1960. Functional and metabolic properties of polymorphonuclear leukocytes. I. Observations on the requirements and consequences of particle ingestion. J. Exp. Med., 111, 667.

Coleman, G. E., AND MeYer, K. F. 1922. Some observations on the pathogenicity of B. botulinus. J. Infect. Dis., 31, 622.

Davis, J. B., Mattman, Lida H., AND Wiley, Marjorie 1951. Clostridium botulinum in a fatal wound infection. J. Am. Med. Ass., 146, 646.

Dolman, C. E. 1961. Further outbreaks of botulism in Canada. Can. Med. Ass. J., 84, 191.

Donadio, J. A., ANd Gangarosa, E. J. 1970. Surveillance for botulism in the United States, 1968-1969. J. Infect. Dis., 122, 122.

Duda, J. J., AND SlaCK, J. M. 1969. Toxin production in Clostridium botulinum as demonstrated by electron microscopy. J. Bact., 97, 900.

Grecz, N., ANellis, A., AND Schneider, M. D. 1962. Procedure for cleaning of Clostridium botulinum spores. J. Bact., 84, 552.

Grecz, N., WAGENAAR, R. O., AND DACK, G. M. 1965. Storage stability of Clostridium botulinum toxin and spores in processed cheese. Appl. Microbiol., 13, 1014.

Harrell, W. K., Green, J. H., AND Winn, J. F. 1964. Preparation, evaluation, and use of $C$. botulinum antitoxins. In Botulism, proceedings of a symposium, edited by K. H. Lewis and K. Cassel, Public Health Service Publication no. 999-FP-1, Cincinnati, Ohio, p. 165.

KePpIE, J. 1951. The pathogenicity of the spores of Clostridium botulinum. J. Hyg. Camb., $49,36$.

Minervin, S. M. 1967. On the parenteral-enteral method of administering serum in cases of botulism. In Botulism, 1966, edited by M. Ingram and T. A. Roberts. London, p. 336.

Powell, Joan F., AND Strange, R. E. 1953. Biochemical changes occurring during the germination of bacterial spores. Biochem. J., 54, 205.

Sbarra, A. J., AND KarnovsKy, M. L. 1959. The biochemical basis of phagocytosis. I. Metabolic changes during the ingestion of particles by polymorphonuclear leukocytes. J. Biol. Chem., 234, 1355.

Starin, W. A., ANd DaCK, G. M. 1925. Pathogenicity of Clostridium botulinum. J. Infect. Dis., 36, 383.

Suzuki, J. B., Booth, R., AND Grecz, N. 1970. Pathogenesis of Clostridium botulinum type A: release of toxin from $C$. botulinum spores in vitro by guinea pig leukocytes. Res. Commun. Chem. Path. Pharmac., 1, 691.

Suzuki, J. B., Booth, R., Benedik, A., AND Grecz, N. 1971. Pathogenesis of Clostridium botulinum type A: Study of in vivo toxin release by implantation of diffusion chambers containing spores, vegetative cells, and free toxin. Infect. Immun., 3, 659.

SUZUKI, J. B., BOOTH, R. R., AND GRECZ, N. 1971a. Evaluation of phagocytic activity by ingestion of labelled bacteria. J. Infect. Dis., 123, 93.

SUZUKI, J. B., Booth, R., AND GRECZ, N. 1971 b. In vivo and in vitro release of ${ }^{45} \mathrm{Ca}$ from spores of Clostridium botulinum type A as further evidence for spore germination. Res. Commun. Chem. Path. Pharmac., 2, 16. 
TANG, T., AND Grecz, N. 1968. Study of spore toxin in germinating spores of Clostridium botulinum 33A. Bact. Proc., p. 2.

Thomas, C. G., JR, Keleher, M. F., AND MCKee, A. P. 1951. Botulism, a complication of Clostridium botulinum wound infection. Archs Path., 51, 623.

United States Public Health Service 1971a. Type A botulism from wound infection, Palo Alto, California. Morbid. Mortal., May 22, 1971, 20, 183.

United States Public Health Service 1971b. Wound botulism, Nebraska. Morbid. Mortal., Dec. 18, 1971, 20, 453, 458.

Wynne, E. S., Schmieding, W. R., and Daye, G. T., JR 1955. A simplified medium for counting Clostridium spores. Fd Res., $20,9$. 